\title{
病期に応じた関節リウマチのリハビリテーション
}

\section{RA における介護保険の現状}

\author{
北里大学東病院リハビリテーション科 前田 真治
}

平成 12 年 4 月より介護保険制度が施行され 3 年以上が経過し， RA は 40 歳以上であれば 第 2 号被保険者として介護保険の利用が可能である. しかし, 多くの介護保険対象者は RA の障害像とは異なる点も多く介護保険が RAに適しているかは検証しなければならない. そ こでRA 患者が社会生活を円滑に行うために，介護保険の現状と今後の問題点を明らかにす ることを目的に，RAの介護保険の利用状況や ADL，QOL を調査した.

【対象】国立相模原病院・北里大学東病院に通院・入院している 40 歳以上の RA 患者で 13 年 度 248 名, 14 年度 157 名を対象に 2 年間調査した.

【方法】調査項目は, 介護保険の認知度, 申請の有無, 介護度, サービス利用内容, 疼痛尺度 の VAS，QOL などである.なお，QOL の評価には，機能障害の程度 MHAQ と，AIMS 変 法，日常生活満足度（SDL），健康関連 QOL（SF-36）を使用した。

【結果】介護保険の認知度は平成 13 年 $67 \%$ が，14 年には $98 \%$ となっていた。しかし, 申請 者は平成 13 年 63 名 $(25 \%), 14$ 年 47 名 (30\%)〔認定者は平成 13 年 53 名 $(21.4 \%), 14$ 年 44 名 $(28 \%)$ 〕 と若干の伸びに止まった. 未申請の理由に, 既存の介護者介護で充足, 生活 体系の混乱などがあった. 介護保険サービス利用は平成 13 年 37 名（認定者の $70 \%$ ), 14 年 39 名 (89\%) である. 内容は, 訪問看護 52 名, 福祉用具の貸与・購入費支給 26 名, 通所介 護 18 名, 訪問入浴介護 16 名, 住宅改修 13 名, 訪問看護 7 名, 訪問リハ・短期入所・通所リ 八各 2 名，居宅療養管理指導 1 名（延べ数）であった。介護度によるVAS 值に差はないが， MHAQ は相関（ $\mathrm{r}=0.823 ）$ を認めた. AIMS 変法は, 身体的要素は介護度の重度化に伴い 低下，社会的要素ではその傾きが緩やかとなり，精神的要素に至っては殆んど低下がみられ なかった. SDL は身体機能, 家庭生活, 社会生活, 勤労生活, 自己啓発, 趣味, 所得・資産 で認定群と未申請群を比較したが, どの項目も差はなかった. SF-36では国民偏差值と身体 面で差はあるものの, 申請, 未申請間での差はなかった.

【考察・結語】介護保険の認知は 14 年度には定着したように思われる。しかし，疼痛の程度 は介護度に反映されず，AIMS，SDL，SF-36 のいずれの QOL 評価も身体的機能には影響す るが, 精神・心理・社会的な面での QOL への貢献度は乏しく, 介護保険の目標とする QOL の向上には RA 特有のアプローチが必要と思われる. 疼痛や関節破壊に応じた在宅サービス や RA 患者などのやや若年層を対象とした通所サービスなどの展開にその余地があるかもし れない. 介護度認定・サービスプラン立案の際にもRA 自体の理解が必要で, 患者の自立支 援という観点から心理面を含む QOL 向上に，専門的知識をもつリ八医療職がさらに介入する ことで果たす役割は大きい. 